students. A register of its members' research interests and publications is published on a two-yearly basis-the next copy is being compiled now and is a valuable research resource.

The Society's activities are wide-ranging, including networks on specific issues such as student development, funding, further education/higher education, vocational higher education, postgraduates, and managing innovation. Frequent seminars and conferences are also held on a variety of themes. The next annual conference, at Lancaster University, England, in December, will examine the issue "the globalization of higher education."

The most recent development has been the involvement of the Society in the UNESCO World Conference on Higher Education. As an NGO of UNESCO, SRHE has been invited to send a full delegation to the conference, and the director, Heather Eggins, will be presenting at the conference.

The Society sees an important international role in encouraging research to be undertaken into higher education and disseminating the findings, and is currently working with UNESCO to ensure that the actions that arise out of the World Conference will enable a better flow of information to be established worldwide between researchers in higher education and policymakers whose decisions shape higher education.

For information about membership see the Society's website at <http://www.srhe.ac.uk/srhe/>.

\section{The Association of Jesuit Colleges and Universities: Service for the Jesuit Higher Education Community}

\section{Charles L. Currie, S.J.}

Charles L. Currie, SJ is president of the Association of Jesuit Colleges and Universities. Address: 1 Dupont Circle, Suite 405, Washington DC 20036. Fax: 202/862-8523.

The Association of Jesuit Colleges and Universities (AJCU) was established in 1970 for the "support and promotion of Jesuit higher education by facilitating cooperative efforts among and providing services to its member institutions, providing a forum for the exchange of experience and information, and representing the work of Jesuit higher education at the national and international levels."

We are a service, not a policy organization. The service focuses on relationships, first among the 28 Jesuit colleges and universities in the United States, and then with Jesuit higher education institutions around the world, with other higher education associations (especially here in Washington), with the Congress and federal government, and with Church and Society of Jesus officials.

In our office in Washington, we are surrounded by pictures from all 28 campuses to remind us who our bosses are. Every day we receive reports and publications from across the country telling us of the many good things happening in Jesuit schools today. It is a fascinating story, not only of very different, but of very similar institutions doing interesting, important things, trying new ideas, attempting solutions to difficult problems, looking to the future with optimism and creativity. I see an increasing sense of a network of women and men already working together, and who want to work even more closely together. Part of our job is to facilitate that.

The 28 presidents look for ways to collaborate even as they engage in friendly competition. In so doing, they look for input from the 30 conferences, many of which regularly consult among themselves (e.g., by e-mail listserves). A number of conferences are working with one another. For example, the Conference of Deans of Adult and Continuing Education and the Conference on Information Technology are cooperating on a distance-learning project involving all 28 institutions. They are exploring the possibility of a national and international distancelearning network of Jesuit institutions. The Conference of Library Directors and the Conference on Information Technology recently held a joint meeting to discuss their common concerns. Members of these conferences like being able to work together in support of one another and toward common goals.

Twenty-six Jesuit business school deans recently established a joint MBA program with Peking University in China. A number of our schools have important linkages with Jesuit universities throughout the world. I recently met with leaders of the 23 Latin American Jesuit universities to investigate ways that we can collaborate to address global concerns like poverty, development, and the environment.

There is a growing sense across the country and indeed around the world that Jesuit alumni and alumnae have something special to share. We are part of a worldwide group of men and women who have experienced a Jesuit education in about 190 Jesuit colleges and universities operating in 66 countries. In the United States alone, there are about 1.5 million living graduates, over 40,000 of whom graduated this past spring.

These are just a few comments on the reality of the partnership that is Jesuit higher education today, and on the legitimate pride we can have in being part of an ongoing success story.

More on the AJCU and member institutions can be found at: http://www.ajcunet.edu/ 